УДК 51-76; 004.11

МРНТИ 27.35.21; 30.17.51

DOI 10.55452/1998-6688-2021-18-2-39-44

\title{
BIOMETRIC IDENTIFICATION OF A PERSON BY SEVERAL PARAMETERS
}

\author{
ZIYATBEKOVA G.Z. ${ }^{1,3}$, ALIASKAR M.S. ${ }^{1,2}$, ABZHALILOVAA.A. ${ }^{2}$, \\ MONTAEVA D.N. ${ }^{2}$, TURLYBEKOVAA.N. ${ }^{2}$ \\ ${ }^{I}$ Institute of Information and Computational Technologies, 050000, Almaty, Kazakhstan \\ ${ }^{2}$ Al-Farabi Kazakh National university, 050000, Almaty, Kazakhstan \\ ${ }^{3}$ Kazakh National Agrarian university, 050000, Almaty, Kazakhstan
}

\begin{abstract}
The article is devoted to the development of a system of biometric identification of a person by face, fingerprints and voice. Two-dimensional and three-dimensional characteristics of a person's face, taking into account area and volume, were used as informative signs of biometric identification of a person by face. A complex identification algorithm has been developed to account for such phenomena as portrait shift, different photo scales, and the tilt of the identified face. The FPM10A scanner and the Arduino microcontroller are used for biometric identification of a person by fingerprints.

Identification signs are based on the analysis of the structure of papillary patterns on the finger: type and type of papillary pattern; direction and steepness of streams of papillary lines; the structure of the central pattern of the pattern; delta structure; the number of papillary lines between the center and the delta and many other signs. Another type of feature is local. They are also called minutiae (features or special points) - unique features inherent only in a particular print, determining the points of change in the structure of papillary lines (end, split, break, etc.), the orientation of papillary lines and coordinates at these points. Each print can contain up to 70 or more minutations.

For biometric identification of a person by voice, MFC and PLP algorithms for digital processing and analysis of audio recordings are used. Various algorithms are used for acoustic speech analysis: hidden Markov models, a model of a mixture of Gaussian distributions. The result of determining the tone of speech and the content of speech for the purposes of voice identification is obtained.

The Visual FoxPro DBMS has developed a «multiparametric automated system for biometric identification of an individual».
\end{abstract}

Keywords: information security, two-dimensional and three-dimensional image, identification, papillary patterns, voice characteristics, human speech, acoustic modeling.

\section{ТУЛҒАНЫ БІРНЕШЕ ПАРАМЕТРЛЕР БОЙЫНША БИОМЕТРИЯЛЫК СӘЙКЕСТЕНДІРУ}

\section{ЗИЯТБЕКОВА Г.З.,, АЛИАСКАР М.С., ${ }^{1,2}$ АБЖАЛИЛОВА А.А. ${ }^{2}$, МОНТАЕВА Д.Н. ${ }^{2}$, ТУРЛЫБЕКОВА А.Н. ${ }^{2}$}

${ }^{1}$ Ақ̧параттық және Есептеуіш технологиялар институты, 050000, Алматы, Қазақстан ²л-Фараби атындавы Қазақ Ұлттық университеті, 050000, Алматы, Қазақстан

${ }^{3}$ Қазақ Ұлттыққ аграрлық зерттеу университеті, 050000, Алматы, Қазақстан

\begin{abstract}
Аңдатпа. Мақ̆ала адамды бет, саусақ іздері мен дауысы бойынша биометриялық сәйкестендіру жүйесін жасауга арналван. Адамның бетінің екі өлшемді және үш өлшемді сипаттамалары, аудань мен көлемін ескере отырып, тұлваны биометрияльққ сәйкестендірудің ақпараттық белгілері ретінде қолданылады. Портреттік жылжу, әртүрлі фотосуреттер және сәйкестендірілген адамның қозгалысы сияқты құбылыстарды ескеретін кешенді сәйкестендіру алгоритмі жасалды.

Саусақ іздері бойынша адамды биометриялық сәйкестендіру үшін FPM10A сканері және Аrdиіпо микроконтроллері пайдаланылды. Сәйкестендіру белгілері саусақтагы папиллярлы өрнектердің құрылылмын талдауга негізделген: папиллярлық өрнектің типі мен түрі; папиллярлық сызықтар
\end{abstract}


авындарының бавыты және тік болуы; өрнектің орталық суретінің құрылымын; дельта құрылылығ; орталық пен дельта арасындавы папиллярлық сызықтардың саны және көптеген басққа белгілер. Белгілердің тагы бір түрі-жергілікті. Оларды минуция деп те атайды (ерекшеліктер немесе арнайь нүктелеріне байланыстыл) - папиллярлық сызықтар құрылымының өзгеру нүктелерін анықтайтын (аяқталу, екіге таралу, үзілісті және т.б.), папиллярлық сызықтардың базытын анықтайтын белгілі бір ізге вана тән ерекше белгілер және осы нүктелердегі координаттар. Әрбір саусақ ізі 70 немесе одан да көп минуцияны қамтуы мүмкін.

Адамды дауыспен биометриялық сәйкестендіру үшін MFCC және PLP алгоритмдері иифрлық өңдеу және аудиожазбаларды талдау үшін қолданылды. Сөйлеудің акустикалық талдауы үшін сан түрлі алгоритмдер қолданылды: жасырын Марков модельдері, Гаусс үлестірмесінің құоспасының моделі. Дауыспен сәйкестендіру мақсатында сөйлеу тонын және сөйлеу мазмұнын анықтаудың нәтижесі альнады. «Адамды биометриялық сәйкестендірудің көп параметрлі автоматтандырылван жүйесі» Visual FoxРго ДҚБЖ-да жасалван.

Tүйінді сөздер: ақпараттық қ̧ауіпсіздік, екі өлшемді және үш өлшемді сурет, сәйкестендіру, папиллярлық өрнектер, дауыстық сипаттама, адамның сөйлеуі, акустикалық модельдеу.

\title{
БИОМЕТРИЧЕСКАЯ ИДЕНТИФИКАЦИЯ ЛИЧНОСТИ ПО НЕСКОЛЬКИМ ПАРАМЕТРАМ
}

\section{ЗИЯТБЕКОВА Г.3. ${ }^{1,3}$, АЛИАСКАР М.С.,2, АБЖАЛИЛОВА А.А.․, МОНТАЕВА Д.Н. ${ }^{2}$, ТУРЛЫБЕКОВА А.Н. ${ }^{2}$}

${ }^{1}$ Институт Информационных и Вычислительных технологий, 050000, Алматы, Казахстан

${ }^{2}$ Казахский Национальный университет имени аль-Фараби, 050000, Алматы, Казахстан

${ }^{3}$ Казахский Национальный аграрный исследовательский университет, 050000, Алматы, Казахстан

\begin{abstract}
Аннотация. Статья посвящена разработке системы биометрической идентификачии человека по лииу, отпечаткам пальцев и голосу. В качестве информативных признаков биометрической идентификации человека по лииу использованы двумерные и трехмерные характеристики лица человека, учитывающие площядь и объем. Для учета таких явлений, как сдвиг портрета, разньй маситаб фотографий и наклон идентифицируемого лица, разработан сложный алгоритм идентификации.

Для биометрической идентификачии человека по отпечаткам пальцев использован сканер FРМ10A и микроконтроллер Arduіпо. Идентификаџионные признаки основаны на анализе строения папиллярных узоров на пальиа: тип и вид папиллярного узора; направление и крутизна потоков папиллярных линий; строение иентрального рисунка узора; строение дельты; количество папиллярных линий между центтом и дельтой и множество других признаков.

Другой тип признаков - локальные. Их также называют минуциями (особенностями или особыми точками) - уникальные признаки, присущие только конкретному отпечатку, определяющие пункты изменения структуры папиллярных линий (окончание, раздвоение, разрыв и т.д.), ориентацию папиллярных линий и координаты в этих пунктах. Каждый отпечаток может содержать до 70 и более минуций.

Для биометрической идентификации человека по голосу использованы алгоритмы MFCC и PLP для цифровой обработки и анализа аудиозаписей. Для акустического анализа речи применены различные алгоритмы: скрытые марковские модели, модель смеси гауссовских распределений. Получен результат определения тональности речи и содержсательности речи для целей идентификации по голосу. На СУБД Visual FoxPro разработана «Многопараметрическая автоматизированная система биометрической идентификации личности».
\end{abstract}

Ключевые слова: защита информации, двухмерное и трехмерное изображение, идентификация, папиллярные узоры, характеристика голоса, человеческая речь, акустическое моделирование. 


\section{Introduction}

The problem of information protection and information security is one of the most important aspects of the development of modern society. Currently, the solution to this problem in the field of development and operation of information systems for various purposes is associated with the development of various requirements to ensure their security and the creation of software and hardware against unauthorized access [1-2].

Automatic human recognition for identification has a large number of applications in various fields. The problems of public security, the need for remote authentication, and the development of human-machine interfaces arouse increased interest in this technology [3].

\section{Methods}

Biometric identification methods are increasingly used in access control systems to workplaces, mobile devices, local and global information resources. Since the implementation of the systems does not require specialized equipment, and the biometric feature cannot be lost, forgotten or transferred, the most promising are systems based on human face recognition.

Authentication methods based on the measurement of human biometric parameters provide $100 \%$ identification. At the moment, biometric systems successfully use the following biometric characteristics for user authentication: iris, fingerprint, palm print, vascular patterns, face geometry, voice print, signature, DNA comparison, which have properties without which their practical application is impossible [4]:

Authentication methods based on the measurement of a person's biometric parameters provide $100 \%$ identification. At the moment, biometric systems successfully use the following biometric characteristics for user authentication: iris, fingerprint, palm print, vascular patterns, face geometry, voice print, signature and DNA comparison, which have properties without which their practical application is impossible [4]:

Universality: each person has biometric characteristics.

Uniqueness: there are no two people with exactly the same biometric characteristics.

Consistency: biometric characteristics must be stable over time.
Measurability: biometrics must be measurable by some physical reading device.

Currently, there are no biometric parameters that combine all these properties at the same time, especially when considering acceptability. Therefore, the use of multiparametric biometric authentication becomes relevant.

\section{Results. Main part}

The Visual FoxPro DBMS was selected for the software implementation of the «Biometric Information Security System».

Visual FoxPro is a Relational Database Management System based on an object-oriented, visually programmable programming language. Starting with the ninth version of Visual FoxPro, a set of GDI Plus and MCI classes is available [5].

The main property of GDI Plus for its use in the software implementation of the workstation «Biometric Information Security System» is the following:

- ability to load and save images from a file, from a table field, or from a variable;

- ability to get information about the image (determining the size of the raster, the resolution of the raster, the graphic format);

- the ability to perform a number of operations on the image (rotation and reflection, clipping a rectangular fragment, resizing the image, interpolation);

- ability to draw independently in the form window;

- ability to print images on the printer.

With MCI, you can record, play back audio and video files of various formats.

Currently included as biological characteristics are «face video», «fingerprint" and «voice».

The following types are introduced for characteristics parameters:

1 - point coordinate; 2 - distance (number); 3 - area; 4 - volume.

The program implements various agglomerative classification algorithms: flexible strategy, nearest neighbor strategy, far neighbor strategy, group mean strategy, centroid strategy, sum of squares strategy [6].

\section{Face video}

A number of parameters have been defined to characterize the «face video», which are:

1) point - coordinates of the pupils of the eyes, bridge of the nose, tip of the nose, 
2) distance - between the eyes, between the bridge of the nose and the tip of the nose, the base of the nose,

3) perimeter - triangle (pupils of the eyes and tip of the nose), triangle (bridge of the nose and base of the nose),

4) area - isolines of the eye sockets, isolines of the nose,

5) volume - eye sockets, nose.

A volumetric $3 \mathrm{~d}$-model, presented as a regular DEM, is used as the initial data for the «face video».

\section{Fingerprint}

The FPM10A module with the Adafruit Arduino library was used to create a biometric fingerprint identification system block [7].

The optical fingerprint scanner is a module that can be used in conjunction with Arduino and other microcontrollers [7]. Capable of storing fingerprints (1000 fingerprints) in memory with their further identification. Used in places of high secrecy, as a kind of password access key based on scanning and verifying fingerprints with a database.

There are two main steps when using a fingerprint sensor. First, data is written into the sensor's memory, that is, a unique ID is assigned to each fingerprint, which will be used for comparison in the future. After recording the data, you can proceed to the "search", comparing the current image of the fingerprint with those recorded in the sensor's memory.

New fingerprints are loaded using the SFG Demo and Arduino IDE programs, assigning a new ID \# to each. All uploaded fingerprint images are encrypted (Figure 1).

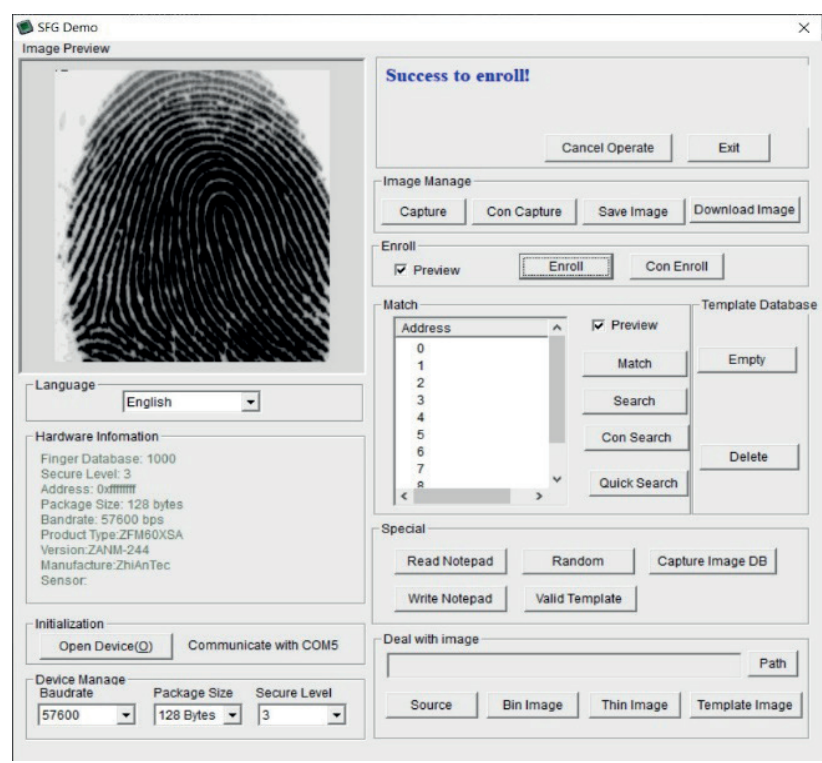

Figure 1 - Uploading the fingerprint to the database

In Figure 2, you can see the percentage of matches. Fingerprints that do not match those stored in the database are ignored by the scanner.

\footnotetext{
(อ) COM5

I

Testing the fingerprint scanner

Sensor detected!

The sensor stores 10 fingerprints

Waiting for fingerprints

Found ID \# 0 matches 100

Found ID \# 5 matches 100

Found ID \# 7 matches 179

Found ID \# 8 matches 100

Found ID \# 9 matches 100

Found ID \# 2 matches 57

Found ID \# 2 matches 100

Found ID \# 7 matches 100

Found ID \# 2 matches 59

Found ID \# 2 matches 74

Found ID \# 2 matches 54

Found ID \# 2 matches 65

Found ID \# 2 matches 100
}

Figure 2 - Fingerprint recognition

Identification signs of the structure of papillary patterns on the fingers are usually subdivided into global and local signs [8].

Global signs include signs that can be seen with the naked eye. These features include: type and type of papillary pattern; direction and steepness of streams of papillary lines; the structure of the central pattern of the pattern; delta structure; the number of papillary lines between the center and the delta and many other signs. 
Another type of signs is local. They are also called minutiae (features or special points) - unique features inherent only in a specific imprint, determining the points of change in the structure of papillary lines (ending, bifurcation, break, etc.), the orientation of the papillary lines and coordinates at these points. Each print can contain up to 70 or more minutes.

\section{Voice}

One of the parameters of biometric personality identification is voice. Voice identification technology is used in various areas of information security, access control systems, forensic science and other areas [8-9].

Oral speech of a person is an ordered system of acoustic signals, which are perceived as a sound image, in the oral speech of a person his individual signs and characteristics are reflected. The individuality of the voice is a consequence of the shape and size of the mouth and nose, throat and respiratory organs. Thus, the physical characteristics of sounds - frequency, duration, intensity - are strictly individual for each person. The task of voice identification is to separate human speech from the input audio stream, its classification and recognition.

Since the human voice is the sum of many separate frequencies created by the vocal cords, there are several features that can be observed and analyzed in the speech of each person:

- Vocal speech (loudness, tempo, stability physical components);

- Tonality of speech (intonation - psychological components);

- Content of speech (vocabulary of a specific person).

\section{Discussion}

The difference in timbres of different voices is described by different frequency spectra. The mathematical apparatus for analyzing the frequency spectrum is the Fourier transform, as a way to describe a complex sound wave with a spectrogram. When calculating the second-order spectrogram, harmonics are identified, which are called «cepstrum», they are not convenient for analysis, since they duplicate information, an example of such a harmonic, uniform background noise or music in a song [10].

\section{Conclusion}

Workstation «Biometric information security system» has been developed. Based on the preliminary classification of objects, the search for a given person in the source database is accelerated. Based on the use of multi-criteria optimization methods, different coefficients are calculated for each class, which allow ranking the criteria by importance. The properties of the proposed mathematical algorithm are investigated. For the first time, the human recognition algorithm takes into account such parameters as the volume of the nose, the volume of the eye socket, and other three-dimensional characteristics. To speed up identification, all data in the source database is pre-classified.

A complex identification algorithm has been developed to account for such phenomena as portrait shift, different photo scales, and the tilt of the identified face. Numerical studies conducted on the model problem have shown the effectiveness of human recognition when changing the scale of a photo. Based on the Arduino microcontroller and the FPM10A scanner, a recognition system has been developed for storing data, further processing it, identifying and displaying fingerprint images. The structure of the structure of papillary patterns on the fingers was selected as identification features. The result of matching fingerprints with different rotations through the scanner is obtained. A promising area is the search for an incomplete fingerprint, since often in practice there is only a part of the fingerprint to search for matches.

The system has developed three algorithms for analyzing audio recordings to solve the problem of biometric identification by voice.

\section{Acknowledgment}

The work was carried out at the expense of grant funding for research for 2020-2022 under the project №AP08856579 «Development of scientific and technological approaches to the production and study of the properties of silicon nanostructures decorated with carbon nanoparticles for modern nanophotonics and sensorics» at the Institute of Information and Computational Technologies, the Committee of science of the Ministry of Education and Science of the Republic of Kazakhstan. 


\section{REFERENCES}

1. G.A. Buzov. Practical guide to identifying special technical means of unauthorized obtaining of information. - M.: Hot line - Telecom, 2010. - 240 p.

2. U.F. Katorin, A.V. Razumovskiy, A.Y. Spivak. Protection of information by technical means. Saint Petersburg: NRU ITMO, 2012. - 416 p.

3. R.M. Bolle, J.H. Connel, S. Pankanti, N.K. Ratha, A.W. Senior. Guide to Biometrics, SprinterVerlag New York, 2004.

4. S. Crihalmeanu, A. Ross. Multispectral sclera patterns for ocular biometric recognition, Pattern Recognition. Lett. 33 (2012)1860-1869.

5. V.B. Klepinin, T.P. Agafonov. Visual FoxPro 9.0. The most complete guide. - Saint Petersburg.: BHV-Petersburg, 2007. - $1216 \mathrm{p}$.

6. S.A.Ayvazyan, V. M. Buchberger, I. S. Enyukov, L. D. Meshalkin. Applied statistics. Classification and dimensionality reduction. - M.: Finance and statistics, 1989. - 607 p.

7. V. A. Petin. Projects using the Arduino controller. - Saint Petersburg.: BHV-Petersburg, 2016. - 464 p.

8. Tan and B. Bhanu. Robust fingerprint identification, in International Conference on Image Processing 2002. - Vol. 1. - IEEE. P. 1-277.

9. Ethan Rublee, Vincent Rabaud, Kurt Konolige, Gary Bradski: «ORB: an efficient alternative to SIFT or SURF», Computer Vision (ICCV), IEEE International Conference on IEEE, 2011. - P. 2564-2571.

10. Dzmitry Bahdanau, Kyunghyun Cho, and Yoshua Bengio. Neural machine translation by jointly learning to align and translate. CoRR, abs/1409.0473, 2014.

\section{Information about authors:}

1. Ziyatbekova Gulzat Ziyatbekkyzy - Doctor PhD, Art. Lecturer of the Department of Information Systems, Faculty of Information Technologies, KazNU named after al-Farabi

ORCID ID: https://orcid.org/0000-0002-9290-6074

Email: ziyatbekova@mail.ru

2. Aliaskar Magzhan Sundetovich - 2nd year PhD student, KazNU named after al-Farabi Email: 87019931011@mail.ru

3. Abjalilova Aisha Akhmetkyzy - 2nd year Master student, KazNU named after al-Farabi ORCID ID: https://orcid.org/0000-0002-2565-3812

Email: aishakz_97@mail.ru

4. Montaeva Diana Narynbekovna - 2nd year Master student, KazNU named after al-Farabi Email: dianamonti24@gmail.com

5. Turlybekova Arailym Nurzhanovna - 2nd year Master student, KazNU named after al-Farabi Email: araylym.turlybekova@samgau.com 